\title{
Research on the Model of Labor Model Culture Integrating Into Ideological and Political Education in Colleges and Universities
}

\author{
Fen Chang
}

\author{
Zhuankou Economic and Technological Development Zone, Wuhan, Hubei Province Jianghan \\ University School of Physics and Information Engineering J05A103, China
}

\begin{abstract}
Labor Mode culture in the new era has positive social effects and values. Through the new era, Labor Mode culture integrates into the mode of ideological and political education in colleges and universities, aiming to find the combination of laomao culture in the new era and ideological and political education in colleges and universities. Enriching the carrier and content of ideological and political education in colleges and universities, and then cultivating the labor spirit of college students, realizing that the ideological and political education in colleges and universities runs through the entire process of education and teaching, and realizes the full course of education and all-round education.
\end{abstract}

Keywords: labor model culture, ideological and political education in colleges and universities, educating people.

\section{Introduction}

In the past 40 years of reform and opening, our country has taken economic development as the center, and the whole country has entered a period of relative peace and stability. In this era of great development and prosperity, cultural self-confidence and road self-confidence, theoretical self-confidence and institutional self-confidence have become important components of socialist thinking with Chinese characteristics. In the "Outline for the Implementation of the Quality Improvement Project for the Ideological and Political Work in Colleges and Universities", it is clearly stated that cultural education is one of the "Top Ten Educating People" systems, emphasizing the need to give play to the teaching function of advanced socialist culture with Chinese characteristics to achieve a cultural person. The effectiveness of educating people. At the National Education Conference in 2018, General Secretary Xi Jin ping enriched the connotation of cultivating socialist builders and successors, transformed the morality, wisdom, physical beauty advocated in the past into morality, intelligence, physical beauty, and labor, and incorporated labor spirit education into the content of ideological and political education in colleges and universities. Enriched the connotation of education.

The culture of working models with Chinese characteristics is the sum of the overall values, labor concepts, beliefs, moral norms, and codes of conduct formed by the long-term practice and innovation of the model workers(hereinafter referred to as "model workers") since the founding of New China, especially since the reform and opening up. Has a lasting influence on the entire society [1]. The new era model culture is a kind of model culture extracted from general secretary Xi Jinping's discussion on labor concept, labor value and labor model spirit since the 18thNational Congress. The new era is the age of the striver. Only struggle can create a happy life. In such an era of advocating labor and struggle, the new era of model labor culture, as an important part of advanced socialist culture with Chinese characteristics, is in harmony with the development of the times, and it is integrated into the ideological and political education work of colleges and universities and meets the requirements of the development of the times. Can play the role of cultural people to educate people.

\section{The Present Situation of New Age Labor Model Culture Integrating into the Ideological and Political Education in Colleges and Universities}

The object of ideological and political education in colleges and universities is the person and the college student. It is an education system that contains various aspects of morality, intelligence, physical integrity, and labor. In long-term ideological and political education in colleges and universities, we pay more attention to the education of students in morality, intelligence, physical 
beauty. The content of ideological and political education is introduced into the related education and teaching activities of morality, intelligence, and physical beauty. The education of labor concept, labor value, and labor spirit has long been missing.

\subsection{The Labor Education of College Students has Long been Absent in Ideological and Political Education in Universities}

Although we know that labor creates happiness, the source of all good life is labor. However, since ancient times, the concept of "professional and excellent, academic and excellent, professional" has made us pay more attention to the cultivation of intellectual education and neglected the importance of labor education. Under the utilitarian educational concept that aims to go to school and obtain an ideal University, labor education is in a state of absence. Often forgotten, it seems that there is no shadow of education in labor, and there is no combination between labor and education.

Before this year's National Education conference, we have long advocated the education system of morality, intelligence and physical beauty. Labor education has been excluded, resulting in a longterm shortage of labor education in higher education institutions. The spirit of struggle embodied in labor and the beauty of labor have always been ignored. Labor not only disappeared in the classroom theoretical teaching, but also disappeared in the colorful social practice. On the one hand, we are complaining that there is no life in the eyes of current college students. On the other hand, it ignores the importance of labor education and connives at the lack of labor education.

\subsection{Some College Students Fail to Establish a Correct Concept of Career Choice}

Human beings are created by labor, and society by labor. There is no distinction between high and low in labor, and any occupation is very glorious [2]. Whether it is family education or the long-term lack of labor education in school education, many students despise physical labor, advocate intellectual labor, and oppose manual labor and intellectual labor. What's more, they classify occupations into 369th, and the most important measure of money. The standard of professional privilege. However, it did not establish the correct concept of career selection.

At present, college students 'career selection values show the characteristics of idealization of career selection goals, utilitarianism of career selection standards, and diversification of career selection intentions [3]. The criteria for their choice of employment are more focused on the superiority of the environment, the level of wages, and the excellent prospects for development. However, the sense of creating value for the society through labor is not enough, and the concept of family and country is weak, and the hardships and hardships of labor are ignored. The problem of structural unemployment has become more and more serious. Many students are too greedy for enjoyment, resulting in hard industries. Some students during the University, the lack of hard work spirit, coupled with the diversification of entertainment methods, led to more enjoyment of life, but failed to pay attention to professional studies, resulting in the inability to achieve high-level employment, creative labor cannot be achieved.

\subsection{There is a Deviation in the Labor Values of Some College Students}

Labor is a source of wealth and a source of happiness. The beautiful dreams of the world can only be realized through honest labor [4]. However, the lack of labor education for a long time has led to deviations in the labor values of some college students. Good and bad labor, hedonism breeding. Under the market economy, the rapid development of society, whether people's material life or spiritual life has become more abundant, the pursuit of higher quality of life has become people's requirements. In the process of pursuing a higher quality of life, there is inevitably a false thought of hedonism. The students 'worldviews, outlook on life, and values on the campus of the university are not yet mature, and they are easily influenced by wrong ideas. There are phenomena of greed, excessive consumption, and luxury consumption. Faced with high consumption, and due to the existence of Internet credit chaos, an ID card, a bank card, and a mobile phone number can be extremely easy and quick to lend money, so that students lost themselves in high consumption, narcissistic. Neglect the truth that labor creates value, and only labor creates a happy life. 


\subsection{The Spirit of the Model has not been Sufficiently Inspiring and the Brand Effect of the Model has not Yet been Formed}

The people of all ethnic groups in the country must learn from the model of labor, take the model of labor as an example, play the spirit of struggling in a hurry, and jointly join in the magnificent cause of realizing the great rejuvenation of the Chinese nation [5]. As an advanced group in all walks of life, the labor model spirit as a spirit should be learned and inherited, but due to long-term neglect of labor education, Neglecting the cultivation of the labor spirit of college students, the model culture is rarely found in the colorful campus life.

The labor model spirit was not publicized in time, and the labor model culture was not actively created. As a result, in the colorful life of college students, the labor model brand was not created, and there was no brand effect. The spirit of labor model has not been able to exert its appeal to college students in the construction of campus culture. The campus influence generated by labor model spirit is insufficient and the labor model brand has not yet been formed.

Second, the significance of integrating labor model culture into ideological and political education in colleges and universities in the new era

In the new era, the integration of labor model culture into ideological and political education in colleges and universities meets the requirements of the times, and broadens the content of ideological and political education work, which is conducive to better training socialist qualified builders and reliable successors.

\section{Practical Path of the New Age Labor Model Culture Integrating into the Ideological and Political Education Work in Colleges and Universities}

The New Age Labor Model Culture has an extremely important significance in the ideological and political education of colleges and universities, actively searching for the combination of labor model culture and college ideological and political education work, and promoting the rapid and efficient integration of labor model culture into the ideological and political education work of colleges and universities in the new era. Promote college students to form correct labor concepts, cultivate correct labor values, promote the spirit of labor model, establish a labor model brand, and give play to the new era of labor model culture for college students Educational guidance.

\subsection{The Whole Process of Ideological and Political Education and Teaching in Colleges and Universities is Integrated into the Culture of Labor Model in the New Era}

Each course embodies the hard work of the industry, fully excavates the materials of labor model culture in each course, integrates the new era labor model culture into all aspects of classroom teaching, and realizes the organic unity of labor model culture and knowledge system education. Cultivate students 'labor spirit in the process of knowledge transfer; In the link of scientific research and education, the creative spirit and innovation level of college students are cultivated, and the creative labor of college students is realized. Practice the teaching of people, guide students to participate in labor practice, improve the labor level and labor ability of college students, through labor experience to create happiness of labor; Excavate the resources of model labor, cultivate the spirit of model labor, and realize the educational effect of culture; Use the network to promote the image of labor model, establish a labor model brand, and cultivate the labor spirit among college students with labor model brands; Expand the mental health education platform, use the positive spirit of the labor model to infect the vast number of young students, cultivate the rational and peaceful psychological state of the students; To provide a platform for students to participate in the management of education and service education, and to increase their talents in dedication to others; Through paid subsidies, students can obtain financial support through work-study and hard work, and play the role of financial support for education; In the process of integrating the whole process of ideological and political education and teaching in colleges and universities and realizing the whole process of educating people, the labor model culture in the new era will give full play to the role of 
the caucus organization in the process of cultivating the spirit of labor and give full play to the effectiveness of organization and education.

\subsection{Strengthening the Publicity and Education of the Core Socialist Values and Reshaping the Labor Values of University Students}

"The model worker is an outstanding representative of the working masses and the most beautiful worker. The model of labor embodied in the model of labor is a vivid expression of the spirit of great times [8]. The core socialist values and the new era labor model culture have their similarities. They integrate the propaganda of labor models into the propaganda of socialist core values, and cultivate socialist core values from a vivid and moving labor model case. Hard work, the courage to innovate, the spirit of indifference to fame and fortune, and the willingness to devote to the labor model, reshape students 'labor values, enable college students to understand the importance of labor to the development of human society and the realization of their own dreams, and allow students to recognize the glory and greatness of labor in their hearts. Respect every labor and every laborer from the heart, and have a more perfect life plan that is more in line with social development. When choosing one's own career, establish a correct concept of career choice in order to meet the needs of the people of the country as the criteria for choice, and truly care for the country and the people.

\subsection{To Develop Colorful Social Practices and Cultivate the Working Spirit of University Students in the Practice of Labor}

By carrying out colorful social practices, students can truly participate in labor practices. On the one hand, they can effectively improve students 'labor literacy and labor standards, combine theoretical learning with the improvement of labor skills, and allow students to feel the firm belief in labor, respect laborers, and cherish labor results. Really realize the ideological and political education that is imperceptible in labor; On the other hand, in the labor practice, students 'labor concept and labor spirit are cultivated, students are allowed to establish correct labor values, feel the charm of labor, and then evolve into conscious labor behavior. Injecting the seeds of struggle into the hearts of young people, so that the majority of young people can overcome difficulties in professional learning and persist in laying a good professional foundation; The value of each profession can be respected and recognized in the process of choosing it; Love labor in life, actively participate in labor, work in the hard work, strive for excellence, combine their dreams with the development of the country, do a line of love, take the model of labor as an example, and strive to cultivate themselves into true great power artisans.

"Practice is the only standard for testing truth." Using the concept of labor practice to help college students establish correct labor concepts, cultivate correct labor values, and realize their dreams in labor.

As an advanced socialist culture, the New Age Labor Model Culture has positive social effects and values. Through the New Age Labor Model Culture integrated into the ideological and political education work in colleges and universities, it aims to find the combination of the New Age Labor Model Culture and the ideological and political education in colleges and universities. Enriching the carrier and content of ideological and political education in colleges and universities, and then cultivating the labor spirit of college students, realizing that the ideological and political education in colleges and universities runs through the entire process of education and teaching, and realizes the full course of education and all-round education.

\section{References}

[1]. Hanchengmin. "The historical logic of the cultural changes of labor models in 40 years of reform and opening up"[ J]. School Party Construction and Ideological Education, November 2018(No. 589): No. 15.

[2]. Xi Jinping. Speech at the Symposium of Intellectual, Model Workers, and Youth Representatives [ N]. Beijing: People's Daily, 2016-04 -30(2). 
[3]. Huang Zhen, Lidongfeng. Under the background of "innovation and entrepreneurship", the cultivation of college students 'correct career selection values [J]. Educational Theory Study, 2017-03-06:187.

[4]. Xi Jinping. Speech at the meeting with the National Model Labor Representative [ N]. People's DayNewspaper, 2013-04-29(2).

[5]. Xi Jinping. Speech at the meeting with the National Model Labor Representative [ N]. Beijing: People's Daily, 2013-04-29(2).

[6]. Xi Jinping. Speech at the Symposium of Intellectual, Model Workers, and Youth Representatives [ N]. Beijing: People's Daily, 2016-04 -30(2).

[7]. Xi Jinping. Xinhuanet: Speech at the Teacher and Student Symposium of Peking University [ EB] (2018-5-3) Http://www.xinhuanet.com/politics/leaders/2018 05/03 / c_1122774230.htm.

[8]. Xi Jinping. Speech at the Symposium of Intellectual, Model Workers, and Youth Representatives [ N]. Beijing: People's Daily, 2016-04 -30(2). 